Chapter 4

\title{
Sustainable Technique for Selected Live Feed Culture
}

\author{
Zaleha Kassim, Akbar John, Lim Keng Chin, \\ Nur Farahiyah Zakaria and Nur Hidayah Asgnari
}

Additional information is available at the end of the chapter

http://dx.doi.org/10.5772/57212

\section{Introduction}

Sustainability in the aquaculture industry depends on several factors including the minimum production cost in comparison to the yield, unexpected environmental conditions which affect the farm and practices in the farm management itself. These factors are inter-connected and always incur a synergistic effect on the issue of sustainability. Live feeds as the fundamental needs for larval rearing and fry production have to be prioritised for sustainable farming activity. Dependency on imported sources of live feeds or inert feed will increase the production cost. Thus, the continued activity of screening, stocking and maintaining some local species as an option for live feed production is economically necessary.

Live feeds are an important basic diet for newly-hatched fish and shrimp larvae as they still have an incomplete digestive system and are lacking in enzymes. They are still at a very young stage to generate their own required nutrients or convert them from any pre-cursor obtained from a diet. They need a ready-made diet with readily available nutrient to be absorbed through their digestive system. There have been many species suggested or tested for their potential as live feed. All test animals were mostly zooplankton in nature and must meet the requirement as live feed. They must be in a compatible size with the mouth size or gape of the larvae predator, or they cannot be swallowed. Since larvae are still weak to track down the food, the wave created by the prey will be a great help, thus 'active' swimming prey is preferred. The most important role of a prey is the ability to supply energy and other nutrients which are essential for the larval survival and growth. Live feeds, as the starter diet in larval rearing and fry production must be continuous in supply. Good, nutritious and compatiblesize prey must be able to reproduce fast to meet the requirement and adaptable to a simple mass-production technique. 


\subsection{Copepods as live feeds}

The conventional live feed, brine shrimp and rotifers, are considered unsuitable as live feed if compared to copepods in term of nutritional value. Artemia sp. is deficient in polyunsaturated fatty acids (PUFAs), thus it needs to be enriched before feeding [1, 2]. Similarly, rotifer have poor nutritional value and are small in size [3]. On the other hand, copepod diets were proven to increase the growth of larval marine fish compared to diet of rotifers Brachionus plicatilis, [4, 5] or Artemia [4]. The potential use of copepods as live feed due to their excellent fatty acid content has been highlighted by using an example, a paracalanid [6]. They improved the quality of the cultured organism, particularly the larval stages. The superiority of copepods over other live feed such as brine shrimp and rotifers was further confirmed [7]. They have the appropriate ratio of docosahexaenoic acid (DHA) to eicosapentaenoic acid (EPA) which will improve the growth and survival of fish larvae if compared to the conventional live feeds [8]. Nonetheless, it is reminded that copepods could be better used as supplement rather than a sole diet in larval rearing, unless they are used for some high-valued commercial reef fish due to the high operation cost [9]. The possibility of using copepods, particularly the harpacticoids as alternative live feed in fish larval rearing has been stressed [10] and it is confirmed that the nutritional quality of harpacticoid copepods as live feed is extremely high $[11,12]$. Macrosetella gracilis, a planktonic harpacticoid copepod, is also reported to have better diet quality when compared to Artemia [13].

Despite these positive findings, rotifers and Artemia continue to be the live feeds of choice in commercial hatcheries, because copepods are not currently cultured at sufficient densities to be economically efficient on a commercial scale $[14,15,16]$. In term of culture condition, it was found that the optimum condition for the high production of a tropical harpacticoid copepod, Pararobertsonia sp., was at salinity 35psu and temperature of $25^{\circ} \mathrm{C}$ [17]. The fluctuation in salinity, $\mathrm{pH}$ and temperature in the culture vessel would definitely influence the reproduction and population growth of copepods such as the harpacticoids if kept in small containers [18]. Nonetheless, a strategy to produce harpacticoid in large quantities for hatchery use by using a tray-culture method has been suggested [19].

Another copepod group, a Cyclopoida, Apocyclops dengizicus was found to increase the survival and growth of Panaeus monodon postlarvae when used as live feed [20]. Cyclopoids are omnivorous, and can be fed a mixture of feeds, mainly phytoplankton or a combination of phytoplankton, yeast or other feeds [7]. As for Apocyclops panamensis, there is a report on a successful technique for outdoor ponds [15]. Information on the use of copepods in aquaculture, particularly from the tropical Apocyclops sp., is still scarce. The species reported in abundance and potentially exploited as live feeds for shrimp post-larvae in Malaysia for example is A. dengizicus. A new species, Apocyclops ramkhamhaengi, has been described [21] and added to the present report of 3 species of Apocyclops recognised from Asia: A. dengizicus (Lepeshkin), A. royi (Lindberg), and A. borneonensis (Lindberg). This new species is found in abundance in eastern Thailand water and has yet to be determined for its potential in aquaculture. Planktonic copepods such as cyclopoids feed on other plankton including planktonic microalgae. To maintain planktonic copepods in the hatchery or aquaculture ponds, a continuous supply of their diet, particularly the microalgae, will definitely be required. 


\subsection{Microalgae}

Microalgae are a diverse group of unicellular autotrophs inhabiting almost all aquatic water bodies. Microalgae are rich in many specific and attractive compounds [22] and their nutritional values for aquaculture had been highlighted [23]. Production of microalgae is mandatory in the hatchery as it is a basic and nutritious diet for live feed, specifically the zooplankton. However, its mass production is generally costly due to huge manpower, space requirements and operation which usually related to the cost of the energy used. A good strategy in manipulating the culture environment, particularly during the production process of microalgae would scale down the operational cost.

Light plays a fundamental role in the development of microalgae through photosynthesis. It is one of the major environmental factors which control the performance of microalgae phototrophic growth and productivity $[24,25,26]$. Light may either be natural or supplied by fluorescent tubes giving the maximum effective radiation which can be absorbed by the pigments of the microalgae. Light intensity plays a vital role, but the requirements vary with the culture depth or volume as well as the density of the algae in the culture. At a higher volume, light intensity must be increased to enable it to penetrate through the culture. However, an extreme light intensity may result in photo-inhibition which reduces the photosynthetic rates and growth $[27,28]$. Furthermore, overheating due to artificial or natural illumination should be avoided in microalgal culture. The most often employed light intensity is 1000 lux which is suitable for Erlenmeyer flasks but 5000-10000 lux is needed for a greater volume of microalgal culture $[29,30]$. The duration of illumination can be varied where photosynthesis of microalgae can be enhanced or increased in the light/dark (LD) cycle (usually 12:12 or 14:10 LD, maximum 16:8 LD). For some microalgae, photosynthesis rate could also be increased exponentially with increasing light/dark frequencies where a longer period of dark in relation to the light period can further increase photosynthetic efficiencies but not vice versa [31]. The illuminations also affect the nutrient utilisation in the culture vessel [32].

A cost-effective and nutritionally-adequate alternative to costly maintenance of live microalgae is the production of moist-microalgae concentrates. It is seen to simplify hatchery procedures and has shown promising potential in the aquaculture industry $[33,34]$.The storing of microalgae concentrates in moist form under low temperature can preserve their high nutrient composition and excellent cell viability [35,33]. Juvenile pacific oyster (Crassostrea gigas) fed with different algal pastes had shown significant improvement in growth rate than oyster fed with other diets [36]. Concentrates of Chaetoceros muelleri and Tetraselmis pseudonana refrigerated for 6 weeks at $4^{\circ} \mathrm{C}$ were found to promote similar survival rates of the tiger prawn Penaeus monodon larvae fed with live microalgae [37]. Supplementation of microalgae concentrates to bivalves, oysters and scallops have also recorded the same extent of growth rates as live microalgae $[38,34]$. It has been documented that most of the demand for mariculture feed in Japan is supplied with live and fresh microalgae which is thickly concentrated and readily stored at $2-4^{\circ} \mathrm{C}$ for 1-8 weeks with good shelf life [39].

Preparation of concentrated condition of microalgae usually involves centrifugation technique. Nonetheless, although this technique has been successfully applied and utilised for preparing microalgae concentrates, it poses some limitations. First, the process involves 
exposure of cells to high gravitational and shear forces deteriorating the cell structure with the leaking of nutritional contents. Second, centrifuging large volumes of cultures is timeconsuming and requires expensive equipments. Several alternative procedures, less damaging to the cells, which can be applied are filtration [40], foam fractionation [41] and flocculation $[33,34,38]$. Previous studies have observed the excellence of ultrafiltration technique in preserving and retaining the cellular structure and properties of fragile algal cells with little loss of material $[42,43]$.

The level of natural resources exploitation for aquaculture purposes is commonly high. Coastal land and mangroves forests always become the target area for brackish-water aquaculture ponds. The water source of this area, which is always from the nearby river estuary and lagoon, is also used as the live feeds (zooplankton and microalgae) source. Nonetheless, the supply is always seasonal and could become unavailable unexpectedly due to many factors and natural phenomena. This chapter aims to discuss the possible ways to produce local live feeds, a marine microalgae species and a planktonic copepod, sustainably using a simple technique for larvalrearing purposes. Maintaining local species is hypothesised to be more economical and practical. The usage of the microalgae as an enrichment element for live feed copepods will be proved.

\section{Methodology}

\section{Experiment 1: Production of Chlorella vulgaris Concentrate Isolated from Bidong Island and Assessment as Copepod Diet}

Seawater samples were obtained from Bidong Island, Terengganu. The collection was made by lowering a Niskin water sampler to a required depth, following the light-penetration depth. Concentrated water samples were then transferred into chilled, white-plastic containers and brought back to the laboratory for microalgae isolation process. Successive plating out on agar plates was performed in order to select the desired marine Chlorella colonies. Monospecific colonies were then transferred into trial culture tubes before scaling up into larger volumes of Erlenmeyer flasks.

The microalgae was then cultured for the preparation of moist concentrates in the temperature controlled room $\left(20 \pm 2^{\circ} \mathrm{C}\right)$ using the standard batch culture method. Triplicate of activelygrowing starter cultures were inoculated into 30 litres acrylic tanks enriched with Conway medium under constant illumination (cool-white type; 110 watts). All cultures were started with an initial inoculum of $2 \times 10^{6}$ cells $\mathrm{mL}^{-1}$. Cultures were aerated continuously using humidified filtered air. Evaporation in the culturing tanks was kept to a minimum by covering the top of the tanks. Cellular density of microalgae cultures was monitored daily using a Neubauer haemocytometer [29]. Scanning electron microscopic observation was also done to determine the ultra structure of the cell. Measurement of radius and height of the target microalgae cells was done under the advanced research microscope (Model Nikon Eclipse 80$\mathrm{i}$, Japan) and twenty individual cells were measured for the calculation of cell biovolume to 
avoid biasing results. Cell biovolume was calculated as assumed round-shape volume with the following formula proposed by Sun and Liu [44]:

$$
\text { Cell volume }=4 / 3 \pi \mathrm{R}^{3}
$$

Where, $\pi=3.142, \mathrm{R}=$ radius of cell

Specific growth rate was calculated from the expression as proposed [45] which is shown below:

$$
\text { Specific growth rate }(\mu)=\ln \left(\mathrm{F}_{1} / \mathrm{F}_{0}\right) / \mathrm{t}_{1}-\mathrm{t}_{0}
$$

Where, $\mu$ specific growth rate, $F_{1}=$ biomass at time harvest, $t_{1}$ and $F_{0}=$ biomass at time zero, $t_{0}$. Doubling time was computed based on the formula as proposed [45] which is shown below:

$$
\text { Doubling time }(\grave{\mathrm{o}})=\log (2) / \mu
$$

Where, $\mathrm{T}=$ doubling time, $\mu=$ specific growth rate.

All microalgae cultures were grown to late-logarithmic phase for the preparation of concentrates via ultrafiltration technique. The concentrated aqueous suspensions of microalgae were filtered through a membrane filter $(0.1 \mu \mathrm{m}$ pore size) to remove access water from the suspension without rupturing the microalgae, thereby obtaining the microalgae concentrate or paste. Cell viabilities of microalgae concentrates were assessed using Eosin dye as a viability assay on the basis of its penetration into non viable-cells based on the expression as proposed [46]:

$$
\text { Cell viability }(\%)=\frac{\text { Viable cells } \times 100}{\text { Total cells }}
$$

The harvesting efficiency or percentage recovery (\%) was evaluated by comparing the remaining total number of cells in the concentrate with the total number of cells before filtration with the following expression:

$$
\text { Harvesting efficiency/Percentage recovery }(\%)=C_{B} / C_{A} \times 100
$$

Where, $C_{B}=$ total number of cells before filtration, $C_{A}=$ total number of cells after filtration

Microalgal concentrates were compared to live cultures of the same algae as food for marine copepods. Copepods were obtained from existing culture in UMT's laboratory. Two different sets of cultures were done using a Petri dish where each of them was fed with live and 
microalgae concentrate respectively. Individual copepods were counted daily under the Leica stereo microscope before being fed ( 1 drop). The maximum specific growth rate $(\mathrm{K})$ was calculated [47] as shown below:

$$
\mathrm{K}=\ln \left(\mathrm{X}_{1} / \mathrm{X}_{0}\right) / \mathrm{t}_{1}-\mathrm{t}_{0}
$$

Where, $K=$ specific growth rate, $X_{1}=$ the number of copepods at harvest time, $t_{1}$ and $X_{2}=$ the number of copepods at time zero, $\mathrm{t}_{0}$

The doubling time was computed as:

$$
\text { Doubling time }(\grave{o})=\log (2) / \mathrm{K}
$$

Where, $\mathrm{T}=$ doubling time, $\mathrm{K}=$ specific growth rate.

\section{Experiment 2: Effects of Photoperiod and Culture Size on Chlorella vulgaris Stock Growth}

Pure strains of Chaetoceros sp. and C.vulgaris were obtained from the microalgae maintenance laboratory at Institute of Tropical Aquaculture, Universiti Malaysia Terengganu, Malaysia, while the pure strain of Nannochloropsis sp. was obtained from the Fisheries Research Centre, Pulau Sayak, Kedah, and was maintained in autotrophic conditions in liquid and semisolid agar with Conway media [48]. This axenic culture was stored at $25 \pm 2^{\circ} \mathrm{C}$ for 3 days which served as an inoculum for further experiments.

Microalgae were grown in autotrophic conditions as a monospecific axenic culture in different volumes $(250 \mathrm{~mL}, 500 \mathrm{~mL}$ and $2000 \mathrm{~mL})$ containing Conway media. $25 \mathrm{~mL}$ of pure strain with the cell density of $\sim 2 \times 10^{6}$ cells $\mathrm{mL}^{-1}$ were transferred to each Erlenmeyer culture flask and kept at complete illumination provided by luminescent tubes (1000 Lux). Carbon source was provided by bubbling sterile $2 \%(\mathrm{v} / \mathrm{v}) \mathrm{CO}_{2}$ in air through the cultures. Culture flasks were maintained at a constant temperature $\left(22^{\circ} \mathrm{C} \pm 1^{\circ} \mathrm{C}\right)$ with the $\mathrm{pH}$ range of $7-8$ and salinity of $\sim 35$ ppt in an air-conditioned laboratory over 2-3 weeks. Daily cell count was calculated using a haemocytometer. To determine the effect of different photoperiods, microalgae cultured in a 2 litre flask containing Conway media was treated at different photoperiods (light/dark) (24:0, 12:12 and 8:16) in replicates and cell count was achieved as mentioned above. Growth curve for each species of algae was constructed and One-way ANOVA with Dunnett's post-test was performed using Graph-Pad Prism.

Mean cell count and specific growth rate were calculated using the formula $X=\frac{\Sigma \chi_{i}}{n}$ and $\mathrm{SGR}=\operatorname{Ln} \frac{W_{2} / W_{1}}{t_{2}-t_{1}}$ respectively (where, $\mathrm{X}=$ mean cell count; $\chi \mathrm{i}=$ total number of cells; ' $\mathrm{n}$ '= number of cell counts; $S G R=$ specific growth rate; $\mathrm{W}_{1}=$ Initial cell density, cell-1; $\mathrm{W}_{2}=$ Cell density at late exponential phase, cell ${ }^{-1} ; t_{1}=$ Time at initial cell density, cell $^{-1} ; t_{2}=$ Time at late exponential phase, cell $\left.{ }^{-1}\right)$. 


\section{Experiment 3: Low-Cost Commercial Fertiliser for Mass Culture of Marine Chlorella vulgaris: Manipulation of N:P:K Ratio}

An investigation was made to see the adaptability of the local marine $C$. vulgaris to the natural conditions in an aquaculture farm. This means that they need to adapt to different fertilisers other than Conway media, different salinity regimes and uncontrolled temperatures. Preparation of NPK-based fertiliser was made by manipulating the ratio of nitrogen, phosphorus and potassium source as summarises in Table 1. Each of the different N:P:K ratio treatments was prepared in triplicate. Source of nitrogen was obtained by using urea fertiliser.

Culture containers were well-cleaned with bleach and rinsed thoroughly before filling up with $1 \mathrm{~L}$ of the farm water (salinity of between 20-25ppt). The marine C.vulgaris concentrate was prepared and $1 \mathrm{~mL}$ of it was inoculated into the container and $1 \mathrm{~mL}$ of the fertilizer was added. The containers were vigorously aerated to provide required quantity of oxygen and to keep cells and media in suspension. The containers were kept in the open under $100 \%$ outdoor light exposure.

\begin{tabular}{cccccc}
\hline & N:P:K ratios & \multicolumn{3}{c}{ Type and fertiliser used } \\
\hline $\mathbf{N}$ & $\mathbf{P}$ & $\mathbf{K}$ & Urea $(\mathbf{g})$ & $\mathbf{P}^{+}(\mathbf{m L})$ & $\mathbf{P o t a s h}(\mathbf{g})$ \\
\hline $\mathbf{1}$ & $\mathbf{1}$ & $\mathbf{1}$ & $\mathbf{0 . 9 8}$ & $\mathbf{0 . 9 8}$ \\
\hline 15 & 15 & 15 & 14.7 & 14.7 & 14.7 \\
\hline 8 & 8 & 2 & 7.84 & 7.84 & 1.96 \\
\hline 16 & 8 & 6 & 15.68 & 7.84 & 3.88 \\
\hline 12 & 6 & 4 & 11.76 & 5.88 & 3.92 \\
\hline 12 & 8 & 4 & 11.76 & 7.84 & 3.92 \\
\hline
\end{tabular}

Table 1. Type and fertiliser used in N:P:K ratio for mass culture of marine Chlorella vulgaris

Sampling of microalgae cells was done daily and counting was carried out using a Neubauer Hemocytometer covered with glass slide under a compound microscope.

The growth rate, divisions per day, and generation time or doubling time was calculated following [49]

$$
\text { Growth rate; } \mathrm{K}^{\prime}=\operatorname{Ln}\left(\mathrm{N}_{\mathrm{t}} / \mathrm{N}_{\mathrm{o}}\right) /\left(\mathrm{t}_{2}-\mathrm{t}_{1}\right)
$$

Divisions per day; Div.day ${ }^{-1}=K^{\prime} / \operatorname{Ln} 2$

$$
\text { Generation time (days); Gen't =1/Div } \cdot \text { day }^{-1}
$$




$$
\text { Generation time (hours); Gen't=24 (1/Div } \left.\cdot \text { day }^{-1}\right)
$$

Where, $\mathrm{No}$ and $\mathrm{Nt}=$ final and initial populations at time $\mathrm{t} 1$ and time $\mathrm{t} 2$, respectively.

Since sample was collected daily, therefore, $\mathrm{t} 2-\mathrm{t} 1=1$.

\section{Experiment 4: Egg Production, Growth and Development of Apocyclops ramkhamhaengi Fed on Marine Chlorella vulgaris}

Detailed observation on the reproduction performance of a zooplankton depending solely on a C.vulgaris diet was planned to prove the important role played by this local microalgae in live-feed production. Samples of copepods were collected from Sungai Semerak ( $\mathrm{N} 05^{\circ} 51.737$, E $\left.102^{\circ} 30.809^{\prime}\right)$, Tok Bali, Kelantan using a zooplankton net. This area receives sea water from the South China Sea, which is near to the Thailand coast where the copepod species was first identified and reported. Live copepods were maintained and adapted to the laboratory environment. Sand-filtered sea water from the Marine Hatchery, Universiti Malaysia Terengganu was diluted with deionised water to be at salinity of 25ppt and was further filtered through a GFC membrane filter and then autoclaved at $121^{\circ} \mathrm{C}$ for 15 minutes [11]. Salinity was measured using a portable hand-refractometer (ATAGO, Japan). Microalgae diet for the copepod was prepared from the marine algae C.vulgaris stocked at the Marine Hatchery. The microalgae were cultured in 29-31ppt Conway medium with 24h-light, room temperature of $25-27^{\circ} \mathrm{C}$ and continuous aeration for 7 days. The cell concentration in each $500 \mathrm{ml}$ conical flask was determined by using Neuber haemocytometer $\left(0.25 \mathrm{~mm}^{2} \times 0.1 \mathrm{~mm}\right)$ under a compound microscope. The algal production was done weekly and supplied to A. ramkhamhaengi culture.

The investigation on the reproduction performance started with fifteen gravid females of $A$. ramkhamhaengi placed into two sets of triplicate of $250 \mathrm{~mL}$ beakers. The diet constituted, $1 \mathrm{~mL}$ of Baker's yeast $(0.02 \mathrm{~g} / \mathrm{L})$ and $1 \mathrm{~mL}$ of C.vulgaris at density $1 \times 10^{6} \mathrm{cells} / \mathrm{mL}$ which were introduced into both sets of the beakers and covered with parafilm layer to avoid contamination. Three subsamples (approximately $1 \mathrm{~mL}$ ) from each beaker of the cultures were observed daily. The number of the copepods at all stages, including nauplii, copepodite, adult and gravid female, were counted under a dissecting microscope (Leica ZOOM 2000) and then returned to the culture. Changing of approximately $80 \%$ of the culture medium was done every alternate day by passing the copepods culture through 100 and 40 microns nylon net which would retain all stages of copepods (the smallest size of 60 microns) but remove most of the waste.

The population growth of $A$. ramkhamhaengi was studied for 30 days. The specific growth rates (K) of all stages of the copepods in both diets given were calculated by using the formula [50]:

$$
\mathrm{K}=\frac{\ln \mathrm{Nt}-\ln \mathrm{No}}{\mathrm{t}}
$$


Where, $t$ is the culture days, No and Nt is the number of copepods at the initial and final selected time interval. The doubling time (Dt) was calculated by dividing $\log _{\mathrm{e}} 2$ by the population growth rate $(\mathrm{K})$ of all stages of $A$. ramkhamhaengi in both diets given:

$$
\mathrm{Dt}=\frac{\log _{\mathrm{e}} 2}{\mathrm{~K}}
$$

Although cyclopoid copepods are known to suspend in water column, A. ramkhamhaengi showed its adaptability to swim on the near bottom of its culture vessel. The culture for this experiment was started by introducing a gravid female on the experimental petri dish. The adult was removed after the eggs hatched and the nauplii were monitored until they reached copepodite-v stage and were ready to mate. Adult females and males from the culture were prepared for the experiment. A pair of male and female was put into each set of glass Petri dish filled with $15 \mathrm{~mL}$ sea water. The use of a Petri dish instead of a beaker eased the daily observation of different stages of the copepod in the population. The cultures were maintained at room temperature of $25-27^{\circ} \mathrm{C}$ without additional oxygen supply or aeration. Observation was done twice per day under a dissecting microscope (Leica ZOOM 2000) before feeding to avoid the disturbance of the diet materials during individual or population counting. The culture medium was changed approximately $80 \%$ daily, and culture containers were subsequently changed every 4 days. Daily feeding was done in the morning and evening by dropping $1 \mathrm{~mL}$ of $1 \times 10^{6}$ cells $/ \mathrm{ml} \mathrm{C.vulgaris} \mathrm{into} \mathrm{the} \mathrm{culture.} \mathrm{The} \mathrm{time} \mathrm{taken} \mathrm{for} \mathrm{the} \mathrm{females} \mathrm{to} \mathrm{become}$ gravid was based on the observation recorded twice per day (morning/evening). Once the females become gravid, the male broodstocks were removed, and the female were left alone inside the Petri dish in order to determine the number of eggs per female from its first copulation. Observation on the development time from nauplii to adult, maturation time and generation time of A. ramkhamhaengi were recorded coupling with the numbers of offspring produced and percentage of hatching.

\section{Result and discussions}

\section{Experiment 1: Production of Chlorella vulgaris Concentrate Isolated from Bidong Island and Assessment as Copepod Diet}

The ultra-structure of the C.vulgaris isolated and cultivated in this study is shown in Figure 1. The scanning electron micrographs displayed the characteristic features of green single cells with spherical shape and possession of rigid cell wall. There are some differences found in the present specimen if compared to some other established species. The outer shell is rough if compared to the latest SEM of C.sorokiana [51].The feature is almost the same as found in SEM of C.vulgaris [52]. In terms of size, the specimen was found to be in between the size of marine C.vulgaris $(2.1 \mu \mathrm{m})$ and estuarine C.vulgaris $(2.3 \mu \mathrm{m})$ from Korean waters [53]. 

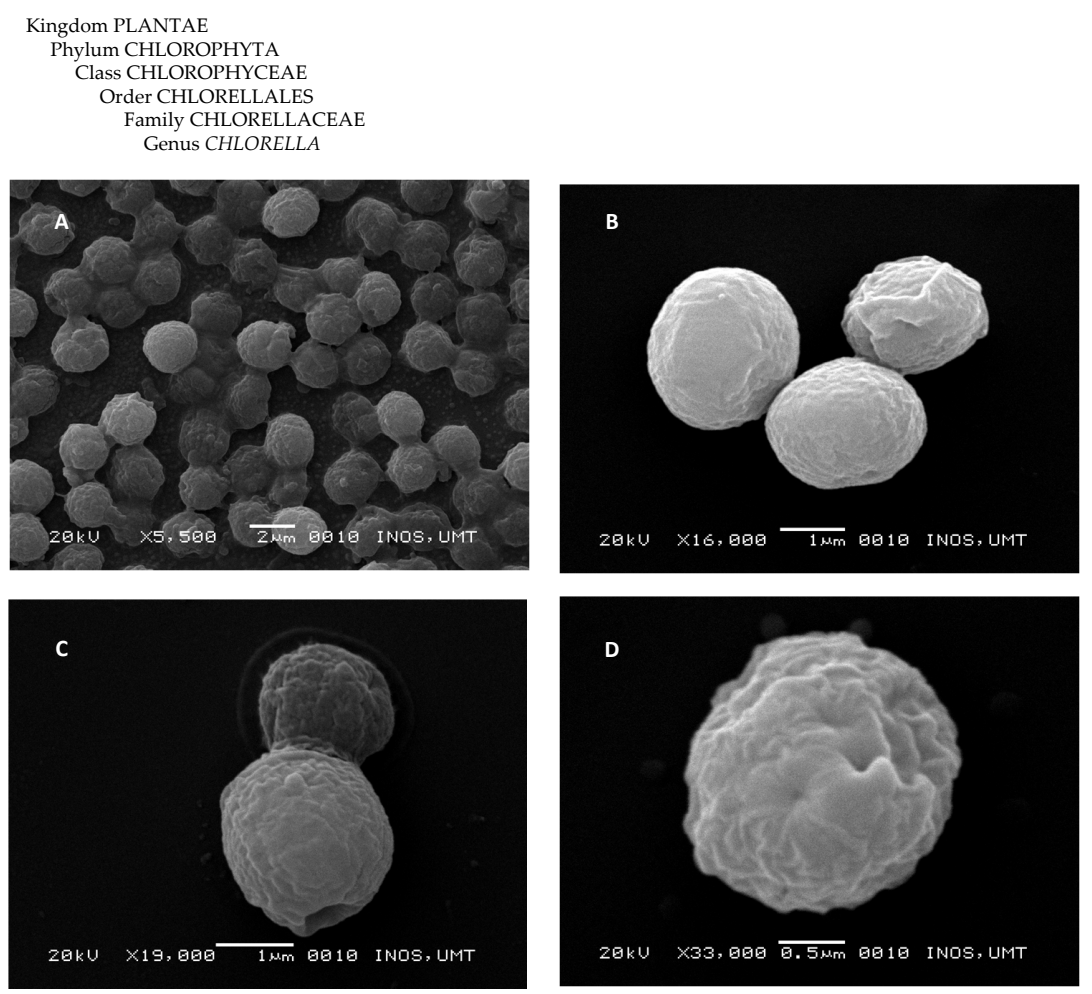

Figure 1. The scanning electron micrographs of C.vulgaris under different views and various magnifications. A, Cell aggregation. B, C.vulgaris cells under different magnification C. Cell divison in C.vulgaris. D, Single cell and cell wall structures.

The cell has an average cell biovolume of $5.26 \pm 0.87 \mu \mathrm{m}^{3}$. The cell densities changed following the culture period in both culture of concentrates (paste) and live condition (although they both started at the same density). Nonetheless, they followed more or less the same growth patten. The variation in cell densities during the experimental period is shown in Figure 2. Cell density of C.vulgaris increased rapidly to $227.22 \pm 0.87 \times 10^{6}$ cells $\mathrm{mL}^{-1}$ prior to stationary phase. After that, the cell densities maintained at this point for ten days before decreasing significantly thereafter (Figure 2). The average specific growth rate (SGR, $\mu$ ) achieved during the exponential phase was $0.660 \pm 0.001$ day $^{-1}$ with the doubling time $(\mathrm{T})$ of $0.580 \pm 0.004$ hour which then decreased drastically to $0.126 \pm 0.001$ day $^{-1}$ during the retardation phase with the doubling time of $2.420 \pm 0.019$ hour before the death phase. Based on cell density and growth rate observed, the following growth phase is described:

i. Exponential (log) phase (days 0-6),

ii. Declining of relative growth rate phase (days 6-12),

iii. Stationary phase (days 12-22), 
iv. Death phase (days 22-26).

C.vulgaris paste was successfully concentrated from the pure culture isolated from Bidong Island. This concentrate contains cell density of approximately $58.46 \pm 2.44 \times 10^{9}$ cells $\mathrm{mL}^{-1}$ $227.22 \pm 0.82 \times 10^{6}$ cells $\mathrm{mL}^{-1}$. The present result also showed that this C.vulgaris concentrate can still be inoculated after refrigeration for a duration of six weeks and exhibited similar growth characteristics as the live culture (Figure 2). The cells had very high viability even after 6 weeks of storage in chilling conditions $\left(4^{\circ} \mathrm{C}\right)$ as shown in Figure 3. It is interesting to note that the paste had recorded the highest cell viabilities of $99.51 \pm 0.57 \%$ and continued to display slow and steady decrement of cell viabilities to $83.28 \pm 0.58 \%$ on the sixth week of storage. Microscopic examination also indicated that the cells were in single forms without any aggregation occurring and can be readily dispersed in seawater medium as single suspension of cells upon inoculation (Figure 1A). The harvesting efficiency of the ultrafiltration technique using membrane filter had recorded a very high percentage recovery of $93.14 \pm 1.35 \%$ showing the effectiveness of this technique for harvesting and concentrating the microalgae biomass.

Copepod species, Apocyclops sp., showed a higher population density when fed with C.vulgaris paste $\left(60 \pm 4.36\right.$ individual $\left.\mathrm{mL}^{-1}\right)$ than with the live culture $\left(14.33 \pm 0.58\right.$ individual $\left.\mathrm{mL}^{-1}\right)$ (Figure 4). In addition, the copepod populations fed with this concentrate exhibited a higher instantaneous growth rate, $K=0.455 \pm 0.008$ day $^{-1}$ and faster doubling time $(0.662 \pm 0.012$ hour $)$ than live culture which recorded an instantaneous growth rate of $0.296 \pm 0.005$ day $^{-1}$ and doubling time of $1.108 \pm 0.016$ hour. Results from one-way ANOVA test has shown that there is a significant difference $(\mathrm{P}<0.005)$ between the copepod population densities fed with the C.vulgaris concentrate and live culture.

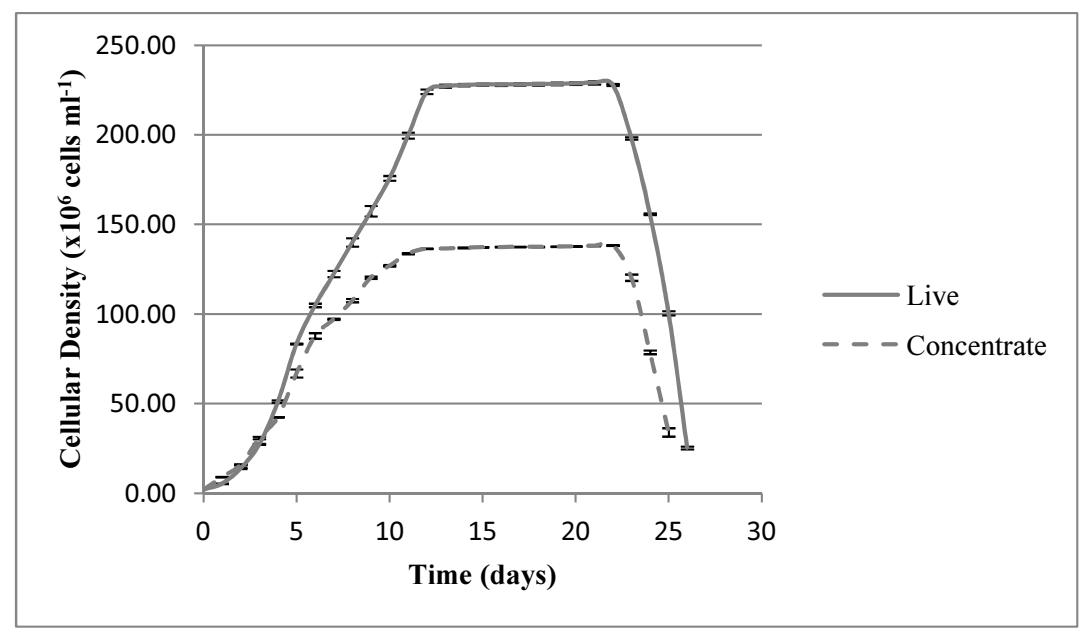

Figure 2. Cellular densities of live C.vulgaris (30L) and concentrate/paste (after reinoculation in $5 \mathrm{~L}$ ) cultured under laboratory conditions with Conway medium. Data are mean value and standard deviation of 3 repetitions. 


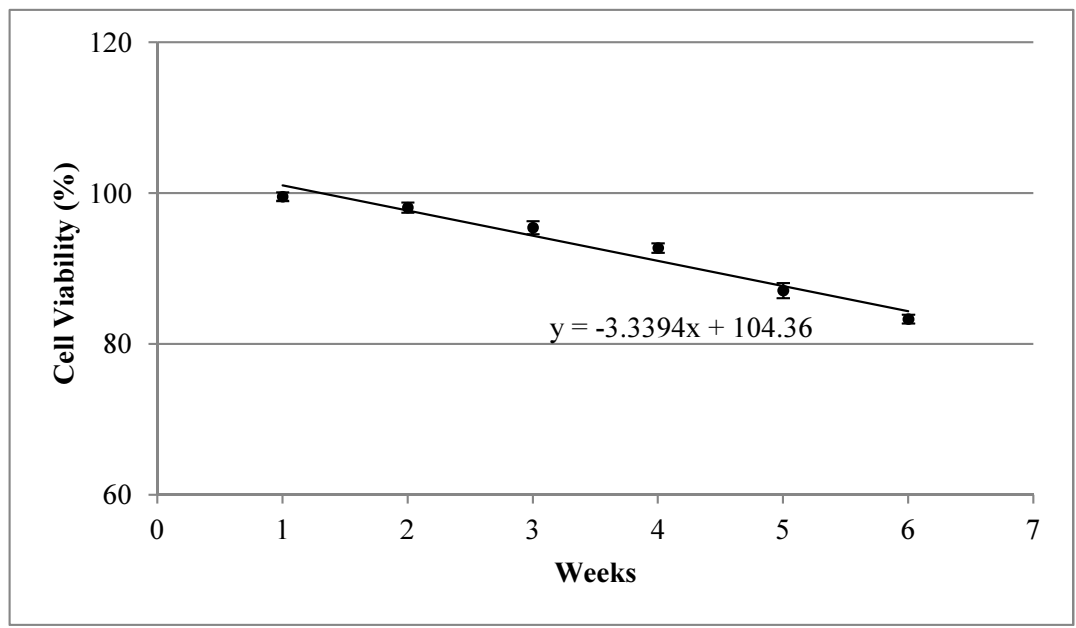

Figure 3. Variations in the cell viabilities of C.vulgaris microalgae concentrate over 6 weeks of storage in chilling condition at $4^{\circ} \mathrm{C}$. Data are mean value and standard deviation of 10 repetitions.

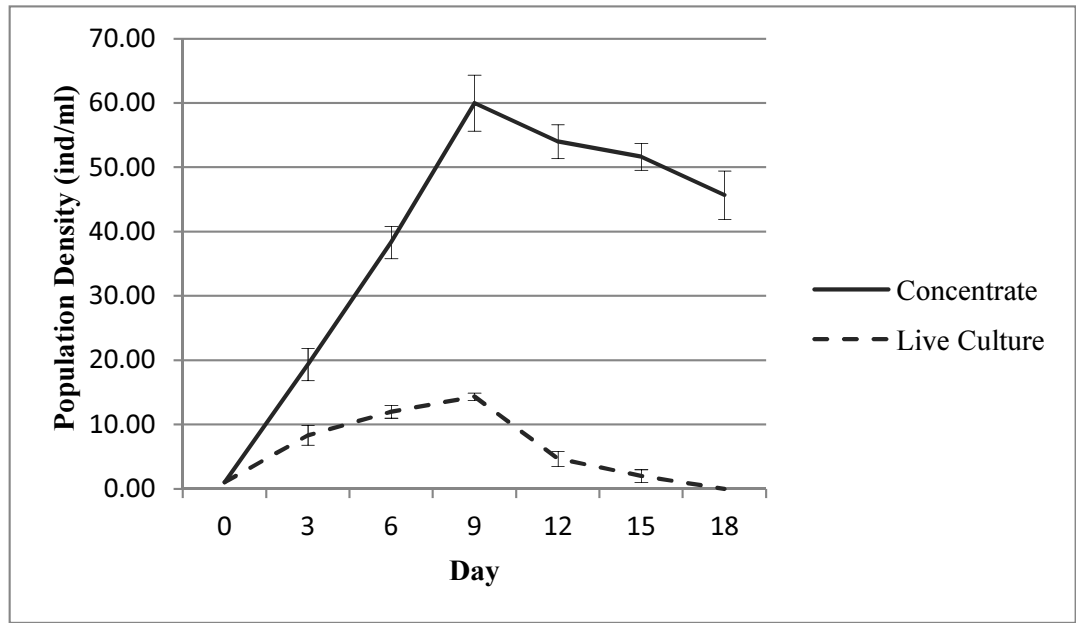

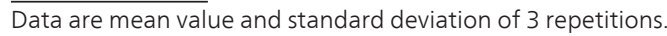

Figure 4. Population densities of Apocyclops sp. fed with live culture and microalgae concentrate of C.vulgaris.

C.vulgaris isolated from Bidong Island had exhibited an extremely rapid growth rate. This might be attributed to its relatively small cell volume with an average of $5.26 \pm 0.87 \mu \mathrm{m}^{3}$. This is indeed much smaller than the cell sizes recorded for some other species; Chaetoceros calcitrans $\left(8 \mu \mathrm{m}\right.$ diameter, volume $\left.276.95 \mu \mathrm{m}^{3}\right)$ and Isochrysis galbana (4 $\mu \mathrm{m}$ diameter, volume 
$33.49 \mu^{3}$ ) [54]. Small size species of microalgae grow faster with a rapid growth rate. This is due to the reason that the greater surface-to-volume ratio of smaller size cells facilitates assimilation of nutrients at a relatively faster rate. In addition, the smaller size cells may achieve high density because they occupy less space. Apart from that, it was also cultured with optimal values for all environmental factors in the laboratory, thus promoting favourable environmental conditions for the cells to grow to extremely high density. In this high-density culture, the possibilities of contamination were excluded. The sudden collapse in the growth rate after day six could be mainly the result of the depletion of the nutrient in the culture. Growth rate declines and growth of microalgae ceases when the nutrient in shortest supply relative to the metabolic needs of algal population $[27,55]$. The populations of C.vulgaris cells then entered the stationary phase of the growth cycle and collapsed after day twenty two. The long stationary phase of this culture might indicate that contamination was absent during the culture period. It has been reported that this stationary phase can last for several weeks if there is no contamination in the culture [30].

The ultrafiltration technique which was used to concentrate the C.vulgaris cells in this study can be applied to concentrate a range of other microalgae species used as aquaculture feeds. Concentrating and storing the microalgae concentrate in moist form preserves its high nutritional value through maintaining excellent cell viability [33,35]. The cells were readily re-suspended upon dilution in sea water with high cell viability which was proven by their ability to be inoculated even after storage for a duration of 6 weeks. The efficiency of ultrafiltration through this study was $\geq 90 \%$ which is very comparable to the reported efficiency of $\geq 80 \%$ for flocculation technique by Knuckey et al. [34]. There has been no comparative assessment of concentrates prepared by ultrafiltration with those prepared by centrifugation. However, from a practical and theoretical point of view, it is proven that the centrifugation method possesses some disadvantages due to its exertion of shear gravitational forces rupturing the microalgae cell structure during harvesting procedure. This reduces their nutritional values due to leaking of nutritional contents. On the other hand, microalgae concentrates prepared by ultrafiltration are not subjected to the same gravitational forces during harvesting. As reported earlier [38], the major production cost of centrifuged concentrates may exceed US\$10,000 (RM32,620) which is unaffordable for small-scale hatcheries and is likely to be limited to larger hatcheries with specialised equipments or facilities specifically set up to produce microalgae concentrates to hatcheries. Advantages of the ultrafiltration technique used in this study is that it is a relatively simple, inexpensive and volume-independent process which can be readily adopted by small-scale hatcheries to prepare their own microalgae concentrates on site.

The use of C.vulgaris concentrate as diet for cyclopoid copepods increases population density, instantaneous growth rate as well as doubling time and it was proven as a better diet than the C.vulgaris live cultures. This might be possibly due to the significantly higher cellular density of the microalgae concentrates. The rates of ingestion and egg production in copepods are dependent on the quantity of the provided microalgae $[56,57]$ implying that quantity of food is the most important factor regulating the productivity of copepod culture. Other studies have also demonstrated that the rate of egg production of calanoid copepod, Acartia tonsa, increases 
with increasing food concentrations $[58,59]$. Essential substances such as cholesterol, HUFA and PUFA are present or exist abundantly in microalgae, and, copepod production is positively related to the lipid levels or DHA: EPA ratio in the diet [60]. Thus, microalgae concentrate could be useful as a replacement for live or fresh microalgae. This is extremely important as a stable and continuous supply of live feed for aquaculture hatcheries must always be provided.

\section{Experiment 2: Effects of Photoperiod and Culture Size on C.vulgaris Stock Growth}

It is very important for hatcheries to be able to maintain the stock for microalgae for their sustainable live-feeds supply. Batch cultures need to be maintained under optimal environmental conditions and in a suitable culture vessel which will not affect the cell density and quality. Comparison on the effect of photoperiod and culture sizes between C.vulgaris and other microalgae was made to investigate the adaptability of the species to simple stock handling in the laboratory or hatchery conditions. No significant difference in the cell density was noted in Nannochloropsis sp. (Figure 5A) and C.vulgaris (Figure 5C) cultures grown in different volume flasks while Chaetoceros sp. Figure 5B showed significant variation in celldensity level at similar culture conditions $(\mathrm{P}<0.001)$. However, stationary phases of all cultured species were achieved earlier in $250 \mathrm{~mL}$ flask compared to the cultures in $500 \mathrm{~mL}$ and 2L flasks. All cultures showed greater response towards daylight variations whereby higher cell density was noted in culture flasks exposed to continued illumination (24:0 L/D), and it was followed by 12:12 L/D and 6:18 L/D condition. Nannochloropsis sp. (Figure 5D) responded less towards the treatment compared to the other 2 species (Figure 5E \& F) which clearly showed a specific response towards culture conditions.

It is well-documented that, in natural conditions, microalgae growth is not curtailed by ambient environmental conditions because the growth rate is just enough for species survival. However, their multiplication rate is highly influenced by various environmental parameters. In an In vitro setup, the proper maintenance of optimum culture condition triggers the metabolic pathway of target species in a unidirectional fashion to achieve high cell density. In this study, a higher cell density of microalgae in low volume flask culture together with early stationary phase was observed could be used to obtain continuous harvest of selected microalgae.

Highest cell density and specific growth rate were recorded in selected species cultured in $250 \mathrm{~mL}$ culture flask compared to the cultures in $500 \mathrm{~mL}$ and $2000 \mathrm{~mL}$ flasks (Table 2). The highest cell density was achieved during the end of the log phase. Cell density of early stationary phase, which is the end of the log phase for Nannochloropsis sp., Chaetoceros sp. and C.vulgaris was achieved on the $10^{\text {th }}$ day of culture in $250 \mathrm{~mL}$. After the $10^{\text {th }}$ day, density decreased and the lowest level was different for different species and different culture volumes. Similar results were also noted for the specific growth rate values. Significant variation in cell density and specific growth rate was observed between the cultures in different sizes of culture flask $(\mathrm{P}<0.05$ or $\mathrm{P}<0.001)$. This observation might probably be due to the lightpenetration efficiency in the culture flask. Similar observation was noted for the culture of Nannochloropsis sp. in $2000 \mathrm{~mL}$ flasks which produced greater cell density compared to the culture in 20L carboys [61]. The effect of light saturation could decrease in the denser culture and the average irradiance in the culture reduced due to absorption from other cells [62]. The 
large volume culture needed higher light intensity to allow light penetration while the smaller volumes were less affected by the light penetration.
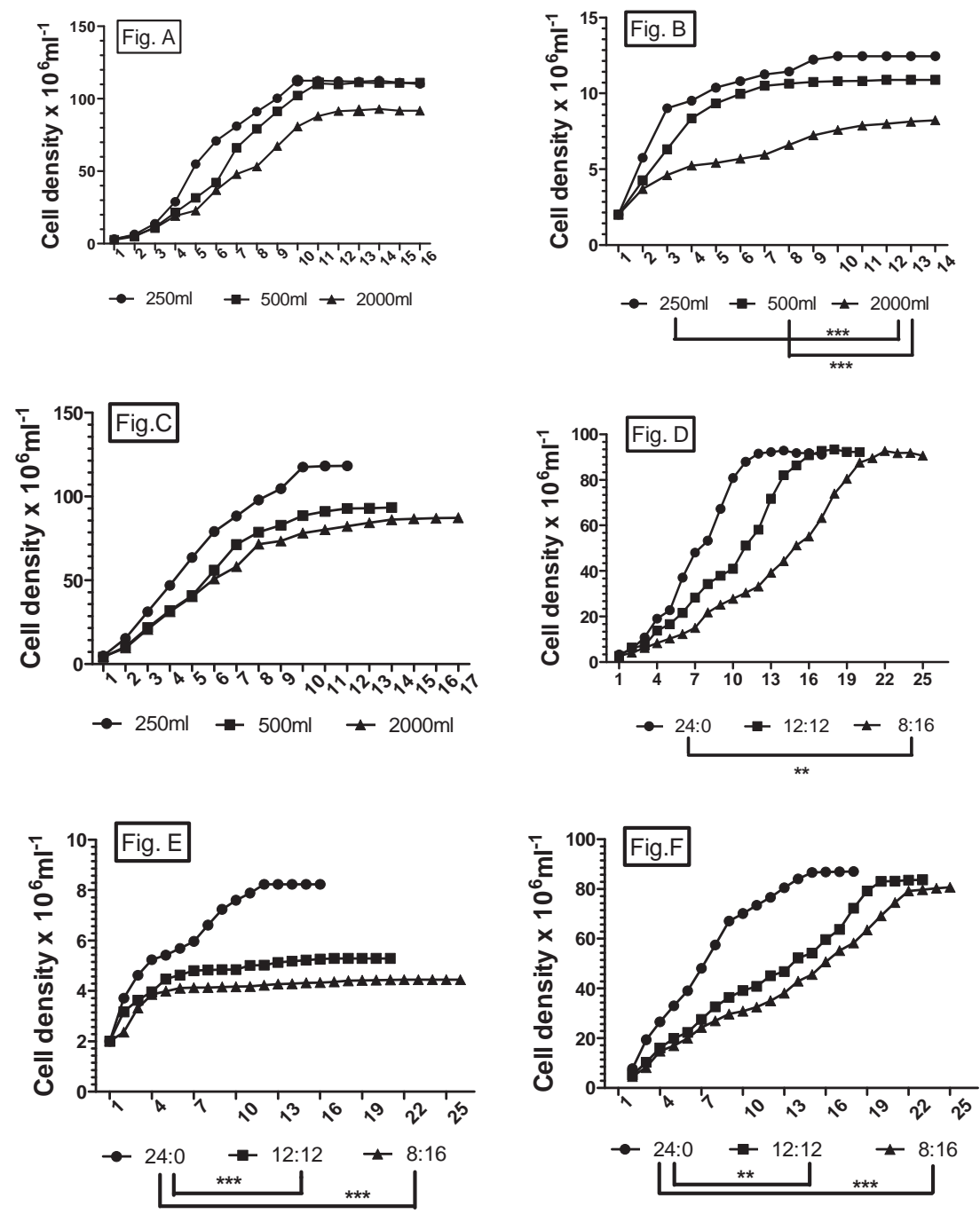

Figure 5. Influence of different photoperiods and culture flask volumes on the cell density of Nannochloropsis sp. (Fig A \& D), Chaetoceros sp. (Fig B \& E) and C.vulgaris (Fig C \& F) respectively. X-axis shows the days of culture. Data represented as $250 \mathrm{ml}, 500 \mathrm{ml}$ and $2000 \mathrm{ml}$ are culture flask volumes while 24:0, 12:12 and 8:16 are photoperiods (Light : Dark phase). $\left.{ }^{* * *}\right]$ and $\left.{ }^{* *}\right]$ are significantly different at $\mathrm{P}<0.001$ and $\mathrm{P}<0.05$ level in the culture conditions respectively. 


\begin{tabular}{|c|c|c|c|c|}
\hline Microalgae & $\begin{array}{l}\text { Flask volume } \\
(\mathrm{mL})\end{array}$ & $\begin{array}{c}\text { Early } \\
\text { stationary } \\
\text { phase }\end{array}$ & $\begin{array}{c}\text { Cell density } \\
\left(\times 10^{6} \text { cells } \mathrm{mL}^{-1}\right)\end{array}$ & Specific growth rate $\left(\mathrm{K}^{\prime}\right)$ \\
\hline \multirow{3}{*}{ Nannochloropsis sp. } & 250 & Day 10 & $112.5 \pm 2.36^{a}$ & $0.52 \pm 0.01^{\mathrm{a}}$ \\
\hline & 500 & Day 11 & $110.17 \pm 1.77^{\mathrm{a}}$ & $0.46 \pm 0.04^{b}$ \\
\hline & 2000 & Day 13 & $92.2 \pm 0.87^{a}$ & $0.34 \pm 0.01^{c^{*}(a c)}$ \\
\hline \multirow{3}{*}{ Chaetoceros sp. } & 250 & Day 10 & $12.460 \pm 0.018^{\mathrm{a}}$ & $0.203 \pm 0.002^{\mathrm{a}}$ \\
\hline & 500 & Day 12 & $10.889 \pm 0.013^{b^{* \star}(a b)}$ & $0.145 \pm 0.001^{b^{*}(a b)}$ \\
\hline & 2000 & Day 14 & $8.225 \pm 0.001^{c^{\star *}(a c \& b c)}$ & $0.037 \pm 0.003^{\left.c^{* *}(a c)\right)^{*}(b c)}$ \\
\hline \multirow{3}{*}{ C.vulgaris } & 250 & Day 10 & $117.53 \pm 0.84^{\mathrm{a}}$ & $0.4749 \pm 0.0007^{a}$ \\
\hline & 500 & Day 11 & $91.0 \pm 0.55^{a}$ & $0.4081 \pm 0.0002^{b}$ \\
\hline & 2000 & Day 14 & $86.13 \pm 0.81^{\mathrm{a}}$ & $0.3166 \pm 0.0007^{c^{*}(\mathrm{ac})}$ \\
\hline
\end{tabular}

Note: Data represented in Mean \pm SD. $\left[^{*}\right]$ and $\left[{ }^{* *}\right]$ indicates significant difference at $\mathrm{P}<0.05$ and $\mathrm{P}<0.001$ (respectively) level between different superscripts depicted for each species.

Table 2. Cell density and specific growth rate of selected microalgae cultured at different flask volumes.

\begin{tabular}{|c|c|c|c|c|}
\hline Microalgae & $\begin{array}{l}\text { Photo period (Light: } \\
\text { Dark phase) in hours }\end{array}$ & $\begin{array}{c}\text { Early } \\
\text { stationary } \\
\text { phase }\end{array}$ & $\begin{array}{c}\text { Cell density } \\
\left(\times 10^{6} \text { cells } \mathrm{ml}^{-1}\right)\end{array}$ & $\begin{array}{c}\text { Specific growth rate } \\
\left(\mathrm{K}^{\prime}\right)\end{array}$ \\
\hline & $24: 0$ & Day 13 & $112.5 \pm 2.36^{a}$ & $0.34 \pm 0.01^{\mathrm{a}}$ \\
\hline \multirow[t]{3}{*}{ Nannochloropsis sp. } & $12: 12$ & Day 17 & $110.17 \pm 1.77^{a}$ & $0.25 \pm 0.01^{b}$ \\
\hline & $8: 16$ & Day 23 & $92.2 \pm 0.87^{a}$ & $0.19 \pm 0.02^{c^{*}(a c)}$ \\
\hline & $24: 0$ & Day 12 & $8.225 \pm 0.001^{a}$ & $0.129 \pm 0.003^{a}$ \\
\hline \multirow[t]{3}{*}{ Chaetoceros sp. } & $12: 12$ & Day 17 & $5.293 \pm 0.009^{b^{* \star}(a b)}$ & $0.061 \pm 0.002^{b^{*}(a b)}$ \\
\hline & $8: 16$ & Day 22 & $4.453 \pm 0.003^{c^{* *}(a c)}$ & $0.037 \pm 0.003^{c^{* *}(a c)}$ \\
\hline & $24: 0$ & Day 14 & $86.60 \pm 0.17^{a}$ & $0.3170 \pm 0.0001^{a}$ \\
\hline \multirow[t]{2}{*}{ C.vulgaris } & $12: 12$ & Day 19 & $83.04 \pm 0.19^{b^{* *}(a b)}$ & $0.2313 \pm 0.0001^{b}$ \\
\hline & $8: 16$ & Day 21 & $79.23 \pm 0.21^{c^{\star *}(\mathrm{ac})}$ & $0.2010 \pm 0.0001^{c^{*}(a c)}$ \\
\hline
\end{tabular}

Note: Data represented in Mean \pm SD. $\left[{ }^{*}\right]$ and $\left[{ }^{* *}\right]$ indicates significant difference at $\mathrm{P}<0.05$ and $\mathrm{P}<0.001$ (respectively) level between different superscripts depicted for each species.

Table 3. Cell density and specific growth rate of selected microalgae cultured at different photo periods.

Highest cell density and specific growth rate were recorded in all cultured species that were exposed to continued illumination (24:0. L/D) followed by 12:12 and 6:18 L/D respectively. Early stationary phases differed for Nannochloropsis sp. (day 13), Chaetoceros sp. (day 12) and C.vulgaris. (day 14) respectively while the corresponding specific growth rate was also highest under 24hours illumination. Significant variation in both growth parameters was observed between the cultures exposed to different photoperiods $(\mathrm{P}<0.05$ or $\mathrm{P}<0.001)$ (Table 3 ). Photosynthetic efficiency of microalgae can be enhanced by sudden alteration between light 
and dark phase [63]. During this process, the fast reduction of e-acceptors, $\mathrm{Qa}$ and $\mathrm{Qb}$, associated to photosystem II (PSII) followed by their oxidation in the dark period will take place that will ultimately maximise the proton-accepting capacity of PSII during sudden irradiant of light [64].

C.vulgaris proved its adaptability to different culture volumes and lighting periods with good growth performance comparable to Nannochloropsis sp. and better than Chaetoceros sp. The cells responded positively towards continuous illumination of light by producing higher cell density and specific growth rate in the culture media. It was also noted that the culture in the low-volume flask produced an early stationary phase due to high penetration of light and continuous sharing of available nutrients in the media for faster growth and survival. On the other hand, C.vulgaris consistently grew at significant cell densities even in larger volume containers and shorter period of illumination than dark condition (comparable to Nannochloropsis sp. and better than Chaetoceros sp.). In another study to analyse the effect of photoperiod to the cellular essential fatty acid in these species, the photoperiod of $12: 12 \mathrm{~h}$ L/D regime is recommended for the fast and economical technique for batch culture production [65]. A better ratio of essential fatty acid accumulated in C.vulgaris exposed in the 12:12h if compared to 24:0 or 8:16 L/D photoperiod.

\section{Experiment 3: Low-cost Commercial Fertiliser for Mass Culture of Marine Chlorella vulgaris: Manipulation of N:P:K Ratio}

C.vulgaris showed its adaptability to grow well when fertilised with a low-cost commercial N:P:K plant fertiliser (Figure 6). Duration of the log phase for C.vulgaris varied among treatments. The 12:6:4 and 12:8:4 ratios had a result of 3 days while the longest period was in the 15:15:15 treatment. Combined applications of urea, $\mathrm{P}+$ and $\mathrm{K}+(\mathrm{N}: \mathrm{P}: \mathrm{K} ; 12: 6: 4)$ produced the highest cell number $\left(4.0 \times 10^{6}\right.$ cells $\left.\mathrm{mL}^{-1}\right)$ during log period at 5 days while N:P:K; 15:15:15 (control) produced highest cell number $\left(4.16 \times 10^{6}\right.$ cells $\left.\mathrm{mL}^{-1}\right)$ at 7 days of log period. Different ratios of N:P:K, 12:8:4, 8:8:2 and 16:4:6 resulted in decrease of cell density, $3.3 \times 10^{6}, 3.0 \times 10^{6}$ and $2.7 \times 10^{6}$ cells $\mathrm{mL}^{-1}$, respectively.

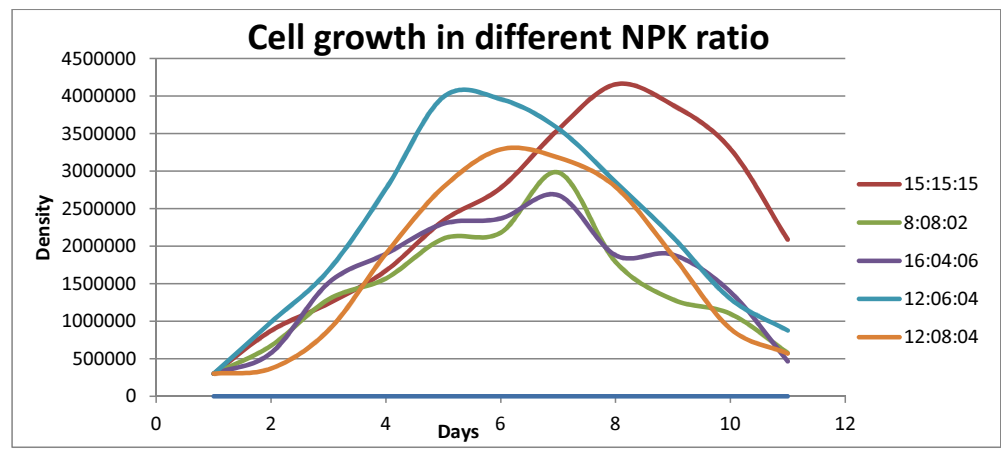

Figure 6. Density (cells $\mathrm{mL}^{-1}$ ) of C.vulgaris cultured with commercial fertiliser of different $\mathrm{N}: \mathrm{P}: \mathrm{K}$ ratios 


\begin{tabular}{clllllll}
\hline \multicolumn{7}{c}{ Days in Log Phase } \\
\hline NPK ratio & 2nd & 3rd & 4th & 5th & 6th & 7th & Average \\
\hline $\mathbf{1 5 : 1 5 : 1 5}$ & 1.07 & Growth rate; K' & & & 0.41 \\
\hline $\mathbf{8 : 0 8 : 0 2}$ & 0.81 & 0.35 & 0.30 & 0.34 & 0.17 & 0.25 & 0.49 \\
\hline $\mathbf{1 6 : 0 4 : 0 6}$ & 0.65 & 0.65 & 0.20 & 0.29 & & 0.51 \\
\hline $\mathbf{1 2 : 0 6 : 0 4}$ & 1.19 & 0.96 & 0.23 & 0.19 & & 0.74 \\
\hline $\mathbf{1 2 : 0 8 : 0 4}$ & 0.20 & 0.53 & 0.50 & & & 0.61 \\
\hline
\end{tabular}

Table 4. Growth rate of C.vulgaris cultured with commercial fertiliser of different N:P:K ratios

\begin{tabular}{|c|c|c|c|c|c|c|c|}
\hline \multicolumn{8}{|c|}{ Days in Log Phase } \\
\hline NPK ratio & 2nd & $3 r d$ & 4th & 5 th & 6th & 7th & \\
\hline & & $\begin{array}{l}\text { on/ Da } \\
\text { day-1 }\end{array}$ & & & & & Average \\
\hline 15:15:15 & 1.54 & 0.50 & 0.44 & 0.48 & 0.25 & 0.36 & 0.59 \\
\hline 8:08:02 & 1.16 & 0.94 & 0.28 & 0.42 & & & 0.70 \\
\hline 16:04:06 & 0.94 & 1.39 & 0.33 & 0.28 & & & 0.73 \\
\hline $12: 06: 04$ & 1.72 & 0.77 & 0.72 & & & & 1.07 \\
\hline 12:08:04 & 0.29 & 1.25 & 1.11 & & & & 0.89 \\
\hline
\end{tabular}

Table 5. Division per day of C.vulgaris cultured with commercial fertiliser of different N:P:K ratios

The 12:6:4 ratios showed the best average (74\%) growth rates of natural increase at log phase. The second was 12:8:4 with 61\% average growth rate.15:15:15 NPK ratio showed the lowest average growth rate of $41 \%$ (Table 4 ). The C.vulgaris cell in 12:6:4 NPK ratio recorded an average division per day by $107 \%$ which was the best compared to others. In 12:8:4 ratios the average cell division was $89 \%$ and decreasingly followed by $16: 4: 6$ and $8: 8: 2$ for $73 \%$ and $70 \%$ respectively. The control ratio which was 15:15:15 showed the lowest average division which was $59 \%$ (Table 5).

Measurement of generation time for C.vulgaris is summarised in Table 6 and Table 7. C.vulgaris cultured with fertiliser of the ratio 12:6:4 only took 1.09 days (26.22 hour) to complete one generation of replication, the shortest time compared to other treatments. The longest generation time was when using the15:15:15 ratio which was completed in 2.31 days (55.49 hour). The other three intermediate treatments recorded 1.70 (40.82 hour), 1.96 (47.11 hour) and 2.1 days (50.63 hour) for 12:8:4, 8:8:2 and 16:4:6 respectively. When comparing the performance by using all of the growth parameters, N:P:K; 12:6:4 ratio gave the best result with average 


\begin{tabular}{|c|c|c|c|c|c|c|c|}
\hline \multicolumn{8}{|c|}{ Days in Log Phase } \\
\hline NPK ratio & 2nd & $3 r d$ & 4th & 5th & 6th & 7th & \\
\hline & & $\begin{array}{l}\text { ration } \\
\text { ys); Ge }\end{array}$ & & & & & Average \\
\hline 15:15:15 & 0.65 & 2.00 & 2.28 & 2.06 & 4.07 & 2.80 & 2.31 \\
\hline $8: 08: 02$ & 0.86 & 1.06 & 3.55 & 2.38 & & & 1.96 \\
\hline 16:04:06 & 1.06 & 0.72 & 3.04 & 3.62 & & & 2.11 \\
\hline $12: 06: 04$ & 0.58 & 1.31 & 1.39 & & & & 1.09 \\
\hline 12:08:04 & 3.41 & 0.80 & 0.90 & & & & 1.70 \\
\hline
\end{tabular}

Table 6. Generation time (days) for C.vulgaris cultured with commercial fertiliser of different N:P:K ratios

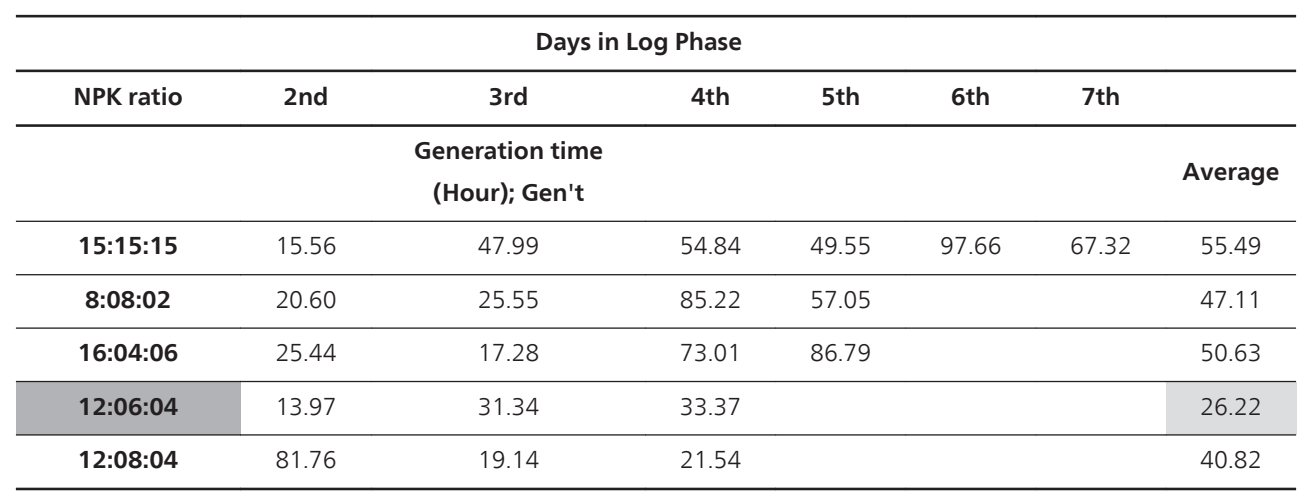

Table 7. Generation time (hour) for C.vulgaris cultured with commercial fertiliser of different N:P:K ratios

growth rate per day $(74 \%)$, maximum growth rate day ${ }^{-1}(107 \%)$, maximum cell density $\left(4.0 \times 10^{6} \mathrm{cell} / \mathrm{mL}\right)$, division's day ${ }^{-1}(107 \%)$ and generation time (1.09 day; 26.22 hour). C.vulgaris in control treatment $(15: 15: 15)$ exhibited the poorest growth performance. Nonetheless, it is interesting to note that they experienced longer log period which could give more time for reproduction activity, thus the density did not decrease drastically as when cultured using other ratios. The fluctuation of temperature and different salinities could be the reason why cell densities were not as high as the first and second experiment.

Numerous nutrient media have been use for the culture of pure Chorella sp. Most of those were for laboratory use and/or for low-grade production of algae. Majority of these media are composed of pure nutrients $(\mathrm{N}-8)$. Commercial fertilisers are least considered for Chlorella culture because of the conception that they do not provide required nutrients for algal growth and are mostly suitable for crop (land) agriculture. Nevertheless, it has been proved that the commercial plant fertiliser could support a freshwater Chlorella [66]. The use of N:P:K fertiliser could be a better choice if compared to the organic fertiliser. Organic matter has its own limitations and depends on the microbial activity to release the inorganic nutrient and it cannot 
be compared to the performance of pure nutrients. Despite good growth performance, the short period of the log phase when C.vulgaris is cultured using N:P:K; 12:6:4 need specific and efficient up-scaling or harvesting method, indicating that other ratios such as 15:15:15 could be a better choice.

\section{Experiment 4: Egg Production, Growth and Development of Apocyclops ramkhamhaengi Fed on C.vulgaris}

Different diets gives significantly $(\mathrm{P}<0.05)$ different densities of $A$. ramkhamhaengi. The mean gravid production of $A$. ramkhamhaengi fed on C.vulgaris and Baker's yeast was highest on $23^{\text {rd }}$ day with 1.11 ind. $/ \mathrm{ml}$ and $0.67 \mathrm{ind} . / \mathrm{ml}$ respectively. The production peaked on $11^{\text {th }}, 23^{\text {rd }}$, and $26^{\text {th }}$ day and on $17^{\text {th }}, 20^{\text {th }}$ and $23^{\text {rd }}$ day when fed with C.vulgaris. and Baker's yeast respectively (Figure 7). In this 30 days culture, the highest mean population density of A. ramkhamhaengi fed with C.vulgaris was recorded on the $9^{\text {th }}$ day with 3.31ind./ml and when fed on Baker's yeast was on day $19^{\text {th }}$ with 1.83 ind./ml (Figure 8). A. ramkhamhaengi fed on C.vulgaris showed the higher instantaneous growth rate (K) than when fed on Baker's yeast (Table 8). The period taken to double their population (Dt) was shorter in A. ramkhamhaengi fed C.vulgaris (8days) than Baker's yeast (11days).

\begin{tabular}{lll}
\hline Diets & Instantaneous growth rate $(\mathrm{K})$ & Doubling Time(Dt)(day) \\
\hline C.vulgaris & 0.1150 & 8 \\
\hline Baker's yeast & 0.0756 & 11 \\
\hline
\end{tabular}

Table 8. The instantaneous growth rate and doubling time of A.ramkhamhaengi fed on different diets.

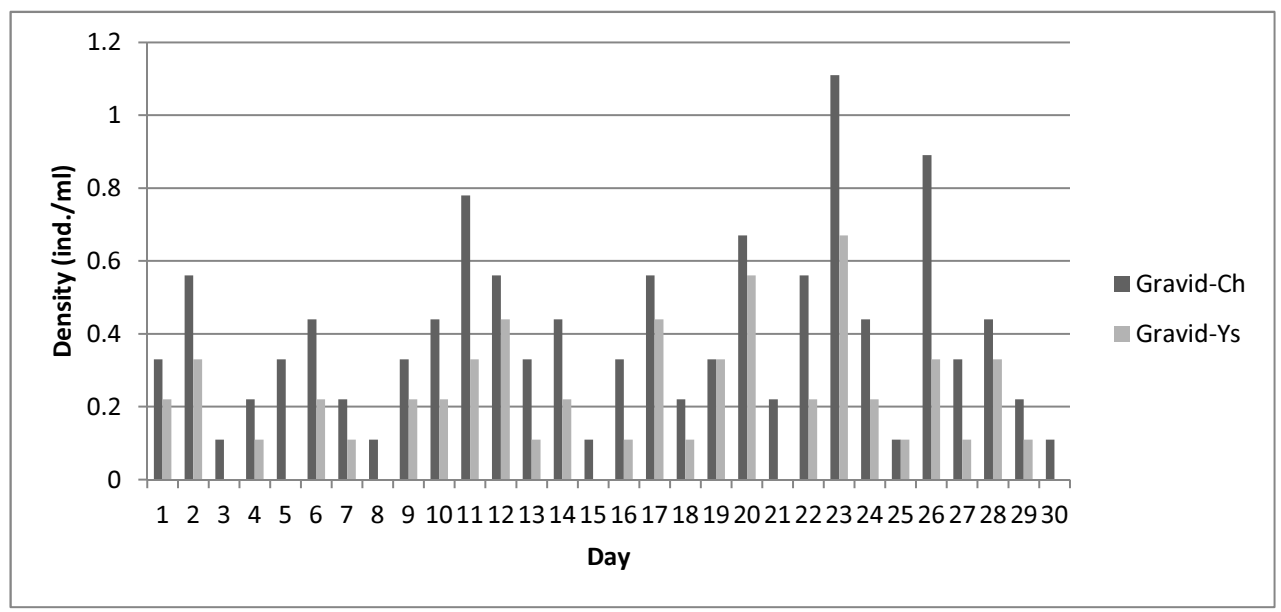

Figure 7. Mean density of gravid female of A.ramkhamhaengi fed with C.vulgaris (Gravid-Ch) and Yeast (Gravid-Ys) in 30 days. 


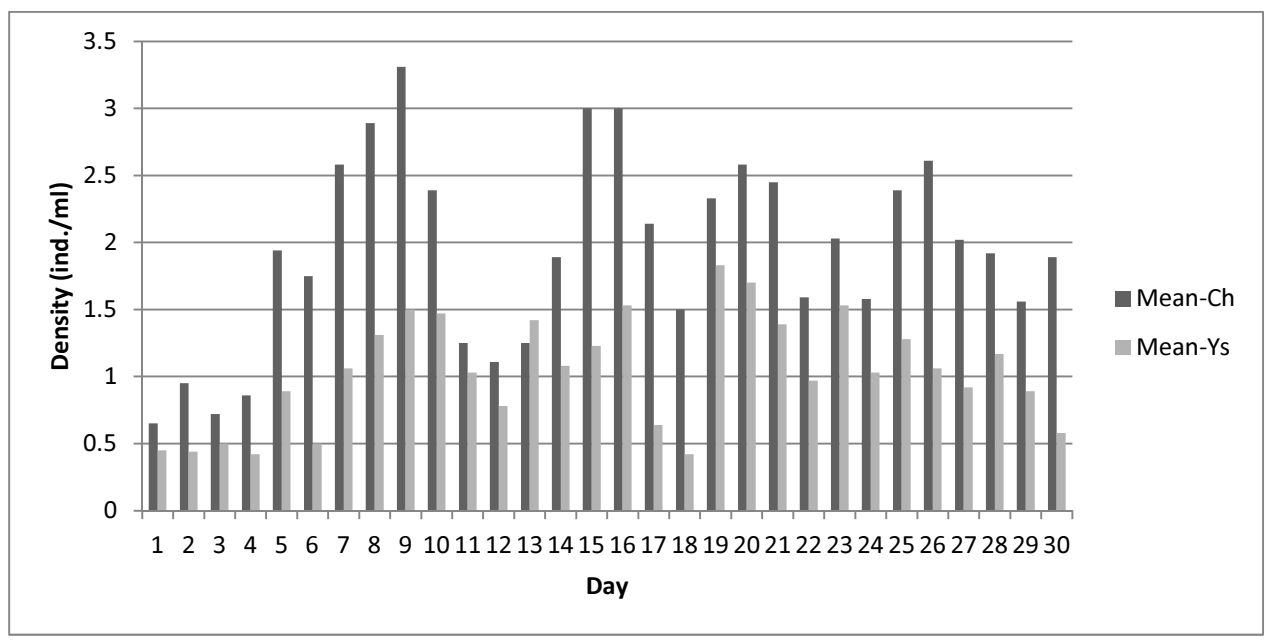

Figure 8. Mean total density of A.ramkhamhaengi fed with C.vulgaris (Mean-Ch) and Yeast (Mean-Ys) in 30 days.

The development times for nauplii, copepodite, adult and gravid female were observed separately using the copepod culture fed on C.vulgaris. The longest period was at copepodite stage $(7.33 \pm 2.08$ days $)$ and the shortest period was the naupliar stage which needed only 1.33 \pm 0.58 days (Figure 9). The mean number of eggs produced was $21.33 \pm 1.53$. Hatching percentage of the three individuals of $A$. ramkhamhaengi was $96.82 \pm 2.77 \%$ (Table 9). Maturation time which is the time between the appearance of eggs and their hatching time was $1.33 \pm 0.58$ days. The time taken to become gravid female from the produced nauplii was about $20.67 \pm$ 3.51days and it is known as generation time.

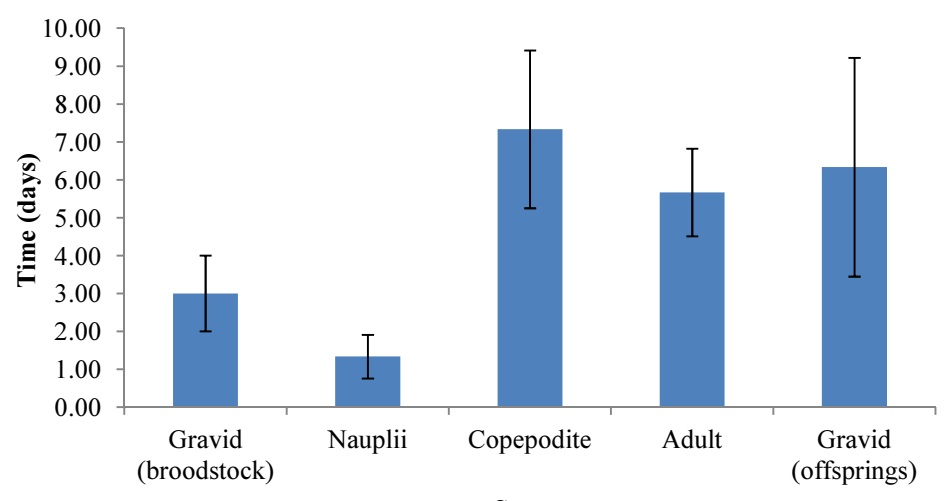

Stages

Figure 9. Mean development time in each stage in A.ramkhamhaengi life cycle 


\begin{tabular}{lllll}
\hline Parameter & N & Mean \pm SD & Minimum & Maximum \\
\hline Number of eggs & 3 & $21.33 \pm 1.15$ & 20 & 22 \\
\hline$\%$ hatching & 3 & $96.82 \pm 2.77$ & 95 & 100 \\
\hline Maturation time(days) & 3 & $1.33 \pm 0.58$ & 1 & 2 \\
\hline Generation time(days) & 3 & $20.67 \pm 3.51$ & 17 & 24 \\
\hline
\end{tabular}

Table 9. The number of observation (N), mean and standard deviation (SD), minimum and maximum of total number of eggs, percentage of hatching of A.ramkhamhaengi, maturation time and generation reared in laboratorycontrolled condition.

Production of the gravid females and the population density obviously increased when $A$. ramkhamhaengi was fed on C.vulgaris as compared to Baker's yeast. This finding is in agreement with the previous study [20] on the population growth and production of $A$. dengizicus fed on different diets. Population reached its peak in term of total density for several periods in the 30day culture condition indicates the existence of different populations. These populations reached their peak density in accordance with the diet taken where Chlorella-fed population were found to grow faster than those fed on Baker's yeast. It seemed that A. ramkhamhaengi has the potential to become more nutritional when enriched, thus growing faster when fed on a good-quality diet such as microalgae if compared to Baker's yeast. The nutritional value has been shown to increase when cyclopoid nauplii stage such as in A. panamensis was offered an enriched diet [15]. Although other microalgal diets such as Tetraselmis sp. and Isochrysis sp. could be a better choice for Chlorella sp. [67], at least the present finding is able to prove the potential of the species to reproduce and grow when fed on the marine C.vulgaris as used in this study.

A female of $A$. ramkhamhaengi fed on C.vulgaris could produce between 20 and 22 eggs with about $97 \%$ hatching success. This is more than what has been reported before for A. panamensis [68], and it could be related to many environmental factors and culture procedure. Environmental parameters such as temperature, food availability and predation were reported to influence the life-history strategy in copepods [69]. Binary diet of Nannochloropsis sp. and TISO improved the hatching rate by $88.1 \pm 2.1 \%$ in a calanoid copepod, Acartia sinjiensis [70]. The brackish water cyclopoid, A. ramkhamhaengi has shown its potential to be cultured and reproduced under controlled conditions. The population adapted very well to the introduced diet, a marine C.vulgaris and a common Baker's yeast. Chlorella-fed population of A. ramkhamhaengi grow faster and need fewer number of days to double its population than those fed on Baker's yeast.The number of eggs produced was $21.33 \pm 1.15$ eggs at the maturation time of $1.33 \pm 0.58$ days and generation time was $20.67 \pm 3.51$ days. The species show great potential to be cultured together with C.vulgaris for hatchery and farm use. A more comprehensive study is essential to investigate the reproductive biology of this species, particularly in a large-scale production system to verify its suitability in aquaculture. 


\section{Conclusion}

C.vulgaris isolated from Bidong Island exhibited a rapid growth rate under optimum environmental conditions in the laboratory culture and was able to achieve an extremely high density when cultured in bigger containers. The photoperiod of 24:0 proved to be the best condition for cells growth but 12:12 L/D photoperiod could be the more economical. The high-density culture could be harvested using a relatively cheap, inexpensive and simple ultrafiltration technique for other use or reinoculation. This will save the space and long period of maintaining live algae for unexpected use. The cells collected using a ultrafiltration technique showed high viability and long shelf life when kept in $4^{\circ} \mathrm{C}$ refrigerator. The product is called as C.vulgaris paste or concentrate which could be used to enrich or maintain the zooplankton live feeds for aquaculture purposes. The C.vulgaris also showed its best growth performance when cultured using a common commercial plant fertiliser with certain ratio of N:P:K. This was shown by their ability to perform cell division and grow and easily adapted to certain ratio such as 15:15:15 and 12:6:4. Nonetheless, the cells density is very much lower than those cultured with the specific chemical fertilizer, Conway media. This problem could be overcome by further investigation on their ion requirement when cultured openly in hatchery or ponds. The suitability of C.vulgaris as enriched diet for a zooplankton potentially used as live feed, A. ramkhamhaengi was proved by the population increase and reached high individual density with good reproduction performance. Maintaining local species of microalgae and zooplanktons in hatchery and ponds will definitely support the continued supply of live feeds for larval rearing and the aquaculture industry.

\section{Acknowledgements}

The authors are grateful to the Ministry of Science, Technology and Innovation (MOSTI) for the funding given under the ABI-MOSTI grant (2009-2011), "Mass fry production technology for grouper (Epinephelus sp.)", the Ministry of Education Malaysia for the Knowledge Transfer Programme grant (2012-2013) Using Microalgae and Copepod Live Feeds for Brackish Water Aquaculture Farm, UMT-PPKJBS.

\section{Author details}

Zaleha Kassim ${ }^{1 *}$, Akbar John ${ }^{3}$, Lim Keng Chin ${ }^{2}$, Nur Farahiyah Zakaria ${ }^{4}$ and Nur Hidayah Asgnari ${ }^{1}$

*Address all correspondence to: zaleha@umt.edu.my

1 Department of Fisheries, Faculty of Fisheries and Aqua-Industry, University Malaysia Terengganu, Terengganu, Malaysia 
2 Institute of Tropical Aquaculture University Malaysia Terengganu, Terengganu, Malaysia

3 Kuliyyah of Science, International Islamic University Malaysia, Kuantan Campus, Malaysia

4 Unit of Farmer's Organisation of South Johor Bahru, Johor, Malaysia

\section{References}

[1] Sorgeloos, P.The use of brine shrimp Artemia in Aquaculture. The brine shrimp, Artemia. 1980. Proceedings the International Symposium on the Brine shrimp, Artemia salina. Universa Press, Wetteren, Belgium. Pp. 25- 46.

[2] Leger, P., Bengtson, D. A., Simpson, K. L. \& Sorgeloos, P. The use and nutritional value of Artemia as a food source. Marine biology and oceanography: an annual review $1986 ; 24,521-623$.

[3] Chu, K. H. \& C. K. Shing. Feeding behaviour of the shrimp, Metapenaus ensis, on Artemia nauplii. Aquaculture 1986; 58, 175-184.

[4] Kuhlmann, D. G., Quantz and Witt, U. Rearing of turbot larvae (scopthalmus maximus) on cultured food organism and postmetamorphosis growth on natural and artificial food. Aquaculture 1981; 23: 183-196

[5] Watanabe, T., and Kiron, V. 1994. Prospects in larval fish dietetics. Aquaculture 1994; 124: 223-251.

[6] McKinnon, A.D., Duggan,S., Nichols, P.D., Rimmer, M.A., Semmens, G. and Robino, B.The potential of tropical paracalanid copepods as live feeds in aquaculture. Aquaculture 2003; 223(1-4), 89-106.

[7] Stottrup, J.G. Review on status and progress in rearing copepods for marine larviculture and advantages and disadvantages among calanoid, harpacticoid and cyclopoids copepods. 2006. VIII Symposium Internacional Acuicola 15-17 Noviembre, Universidad Autonoma de Nuevo Leon, Mexico.

[8] Rajkumar \& Kumaraguru vasagam. Suitability of the copepod, Acartia clausi as a live feed for Seabass larvae (Lates calcarifer Bloch): Compared to traditional live-food organisms with special emphasis on the nutritional value. Aquaculture 2006; 261(2), 649-658.

[9] Schipp, G. 2006. The use of Calanoid Copepods in semi-intensive, tropical marine fish larviculture. VII Simposium Internacional de Nutricion Acuicola. 15-17 Noviembre. Universidad Autonoma de Nuevo Leon, Monterrey, Nuevo Leon Mexico. 
[10] Zaleha,K., Ibrahim, B., Akhbar John, B., Kamaruzzaman, B.Y. Generation times of some marine harpacticoid species in laboratory condition. Journal of Biological Sciences 2012; 12(8), 426-432. DOI: 10.3923/jbs.2012.433.437

[11] Carli, A., Mariottini, G. L. \& Pane, L. Influence of nutrition on fecundity and survival in Tigriopus fulvus Fischer (Copepoda, Harpacticoida). Aquaculture 1995; 134,113-119.

[12] Cutts, C.J. Culture of harpacticoid copepods: potential as live feed for rearing marine fish. Advances in Marine Biology 2003; 44:295-316.

[13] Ananth, S. and Santhanam, P. Laboratory culture and biochemical profile of marine copepod Macrosetella gracilis (Dana). Aquaculture 2011; 12(1): 49-55.

[14] Rhodes. A. 2003. Methods for high density batch culture of Nitokra lacustris, a marine harpacticoid copepod.The Big Fish Bang. In: Howard I. Browman, A., Skiftesvik, B. (eds.) Proceedings of the 26th Annual Larval Fish Conference. Institute of Marine Research, Bergen, Norway.

[15] Sumiarsa, G.S. Cyclopoid copepod nauplii Apocyclops panamensis: mass production method in outdoor ponds and their fatty acid profiles.VDM Verlag Dr.muller $\mathrm{GmhH}$ \& Co. KG. Germany. 2011.

[16] Drillet,G., Frouël,S., Sichlau, M.H., Jepsen, P.M., Jonas K., Højgaard, J.K., Joarder,A.K., Hansen, B.W. Status and recommendations on marine copepod cultivation for use as live feed. Aquaculture 2011; 315:155-166

[17] Zaleha, K., Farahiyah, I. J. Culture and growth of a marine harpacticoid, Pararobertsonia sp in different salinity and temperature. Sains Malaysiana 2010; 39(1): 135-140

[18] Kassim, Z.,Ibrahim, B. Culture of Harpacticoid Copepods: Understanding the Reproduction and Effect of Environmental Factors. In: Muchlisin, Z. (ed.) Aquaculture. Rijeka: Intech; 2012.p343-360.

[19] Rhodes. A. Methods for high density batch culture of Nitokra lacustris, a marine harpacticoid copepod.The Big Fish Bang. In: Browman, H.I., Skiftesvik, A.B. (eds.). Proceedings of the 26th Annual Larval Fish Conference. Institute of Marine Research, Postboks 1870 Nordnes, N-5817, Bergen, Norway. ISBN 82-7461-059-8. 2003

[20] Farhadian, O., Yusoff, M.F., Arshad, A. Population growth and production of Apocyclops dengizicus ( Copepoda: Cyclopoida) Fed on Different Diets. Journal of the World Aquaculture Society, 2008; 39(2), 384-396. DOI: 10.1111/j.1749-7345.2008.00172.x

[21] Chullasorn, S., Kangtia, P., Pinkaew, K.,Ferrari, F.D. Apocyclops ramkhamhaengi sp. nov. (Copepoda: Cyclopoida) in a Culture Originating from Brackish Waters of Chang Island, Trat Province,Thailand. Zoological Studies 2008; 47(3),326-337.

[22] Apt, K. E., Behrens, P. W. 1999. Commercial developments in microalgal biotechnology. Journal of Phycology, 35(2), 215-226. doi: 10.1046/j.1529-8817.1999.3520215.x 
[23] Geudes, A.C., Malcata, F.X. Nutritional values and uses of microalgae in aquaculture. In: Muchlisin, ZA (Ed); InTech Open Acess Publisher

[24] Muller-Feuga, A., Moal, J. and Kaas, R. 2003. The microalgae of aquaculture. In: Stottrup, J.G and Mcevoy, L.A (eds.) Live Feeds in Marine Aquaculture. Blackwell Publishing Ltd., USA, p206-252.

[25] Mata, T.M., Martins, A.A., Caetano, N.S. 2010. Microalgae for biodiesel production and other applications: a review. Renewal Sustainable Energy Review 2010; 14 : 217-232.

[26] Chen, C.Y., Yeh, K.L., Aisyah, R., Lee, D.J. and Chang, J.S. 2011. Cultivation, photobioreactor design and harvesting of microalgae for biodiesel production: a critical review. Bioresource Technology, 102, pp. 71-81.

[27] Lee, Y.K. and Shen, H. 2004. Basic culturing techniques for microalgae. In: Handbook of Microalgal Culture, Biotechnology and Applied Phycology (ed. A. Richmond). Blackwell Publishing Ltd., USA, pp. 40-56.

[28] Chen, C.Y., Yeh, K.L., Aisyah, R., Lee, D.J. and Chang, J.S. 2011. Cultivation, photobioreactor design and harvesting of microalgae for biodiesel production: a critical review. Bioresource Technology, 102, pp. 71-81.

[29] Becker, E.W., 1995. Microalgae biotechnology and microbiology. Cambridge University Press, Great Britain, pp.56- 62.

[30] Borgne, Y.L. 1996. Culture of microalgae. In: Aquaculture (ed. G. Barnabe). Ellis Horwood Ltd., England, pp. 197-206.

[31] Grobbelaar, J.U., Nedbal, L. and Tichy, V. 1996. Influence of high frequency light/ dark fluctuations on photosynthetic characteristics of microalgae photoacclimated to different light intensities and implications for mass algal cultivation. Journal of Applied Phycology, 8, pp. 335-343.

[32] Meseck S.,L., Alix J.,H., Gary, H., Wikfors G.,H., 2005. Photoperiod and light intensity effects on growth and utilization of nutrients by the aquaculture feed microalga Tetraselmis chui (PLY429). Aquaculture 246: 393-404.

[33] Heasman, M., Diemar, J., O'Connor, W., Sushames, T. and Foulkes, L. 2000. Development of extended shelf-life microalgae concentrate diets harvested by centrifugation for bivalve mollusks- a summary. Aquacult. Res., 31, pp. 637-659.

[34] Knuckey, R., Brown, M., Robert, R. and Frampton D. 2006. Production of microalgal concentrates by flocculation and their assessment as aquaculture feeds. Aquacult. Eng., 35, pp. 300-313.

[35] Montaini, E., Zitelli, G.C., Tredici, M.R., Molina Grima, E.M., Fernandez Sevilla, J.M. and Sanchez Perez, J.A. 1995. Long-term preservation of Tetraselmis suecica: influence of storage on viability and fatty acid profile. Aquaculture, 134, pp. 81-90. 
[36] McCausland, M.A., Brown, M.R., Barrett, S.M., Diemar, J.A. and Heasman, M.P. 1999. Evaluation of live and pasted microalgae as supplementary food for juvenile Pacific oyster (Crassostrea gigas). Aquacult. Res., 174, pp. 323-342.

[37] D'Souza, F.M.L., Knuckey, R.M., Hohmann, S. and Pendrey, R.C. 2002. Flocculated microalgae concentrates as diets for larvae of the tiger prawn Penaeus monodon Fabricius. Aquaculture Nutrition, 8, pp. 113-120.

[38] Brown, M. and Robert, R. 2002. Preparation and assessment of microalgal concentrates as feeds for larval and juvenile Pacific oyster (Crassostrea gigas). Aquaculture, 207, pp. 289-309

[39] Iwamoto, H. 2004. Industrial production of microalgal cell-mass and secondary products-Major industrial species: Chlorella. In: Handbook of Microalgae culture, Biotechnology and Applied Phycology (ed. Richmond, A.). Blackwell Science Ltd., Oxford, UK, pp. 255-263.

[40] Rossingol, N., Vandanjon, L., Jaouen, P. and Quemeneur, F. 1999. Membrane technology for the continuous separation microalgae culture medium: compared performances of cross-flow microfiltration and ultrafiltration. Aquacult. Eng., 20, pp. 191-208.

[41] Csordas, A. and Wang, J.K. 2004. An integrated photobioreactor and foam fractionation unit for the growth and harvest of Chaetoceros sp. in open systems. Aquacult. Eng., 30, pp. 15-30.

[42] Petrusevski, B., Bolier, G., Van Bremen, A.N. and Alaerts, G. J. 1995. Tangential flow filtration: a method to concentrate freshwater algae. Water Res., 29, pp. 1419-1424.

[43] Rossingol, N., Vandanjon, L., Jaouen, P. and Quemeneur, F. 1999. Membrane technology for the continuous separation microalgae culture medium: compared performances of cross-flow microfiltration and ultrafiltration. Aquacult. Eng., 20, pp. 191-208.

[44] Sun, J. and Liu, D.Y. 2003. Geometric models for calculating cell biovolume and surface area for phytoplankton. J. Plankton Research., 25, pp. 1331-1346.

[45] Muller-Feuga, A. 2000. The role of microalgae in aquaculture: situation and trends. J. Appl. Phycol., 12, pp. 527-534.

[46] Baraniak, B., Niezabitowskab, M., Pieleckic, J. and Wojcika, W. 2004. Evaluation of usefulness of Magnafloc M-22S flocculant in the process of obtaining protein concentrates from peas. Food Chem., 85, pp. 251-257.

[47] Omori, M. and Ikeda, T. 1984. Methods in Marine Zooplankton Ecology. Wiley, New York, $322 \mathrm{pp}$.

[48] Usha, T.L., Sarada, R., and Ravishankar, G.A. 2002. Effect of culture conditions on growth of green alga Haematococcus pluvialis and astaxanthin production. Acta Physiologiae Plantarum. 24 (3): 323-329 
[49] Fogg and Thake 1987. Algal Cultures and Phytoplankton Ecology. University of Wisconsin Press.

[50] Abu-Rezq, T. S., Yule, A. B. \& Teng, S. K. 1997. Ingestion, fecundity, growth rates and culture of the harpacticoid copepod, Tisbe furcata, in the laboratory. Hydrobiologia, $247,109-118$.

[51] Imase, M., Ohko, Y., Takeuchi, M., Hanada, S. 2013. Estimating the viability of Chlorella exposed to oxidative stresses based around photocatalysis. International Biodeterioration and Biodegradation. 78: 1-6

[52] Dwaish, A.S., Mohammed, D.Y., Jawad, A.M., Al-kubaicy, A.A. Determine the Uptake of Lead in Chlorella vulgaris Isolated from Tigris River in Baghdad City. International Journal of Scientific and Engineering Research, 2011, 2(9): 1-4

[53] Bae, J.H. and Hur, S.B. 2011. Selection of suitable species of Chlorella, Nannochloris and Nannochloropsis in high- and low temperature seasons for mass culture of the rotifer Brachionus plicatilis. Fisheries and Aquatic Sciences, 14(4):323-332.

[54] Phatarpekar, P.V., Sreepada, R.A., Pednekar, C. and Achuthankutty, C.T. 2000. A comparative study on the growth performance and biochemical composition of mixed culture of Isochrysis galbana and Chaetoceros calcitrans with monocultures. Aquaculture, 181, pp. 141-155.

[55] Barsanti, L. and Gualtieri, P. 2006. Algae: anatomy, biochemistry and biotechnology. CRC Press, New York, 301 pp.

[56] Stottrup, J.G. and Jensen, J. 1990. Influence of algal diet on feeding and egg-production of the calanoid copepod Acartia tonsa Dana. J. Exp. Mar. Biol. Ecol., 141, pp. 87-105.

[57] Stottrup, J.G. 2003. Production and nutritional value of copepods. In: Live Feeds in Marine Aquaculture (eds. Stottrup, J.G and Mcevoy, L.A.). Blackwell Publishing Ltd., USA, pp. 145-205.

[58] Kiorboe, T. 1997. Population regulation and role of mesozooplankton in shaping marine pelagic food webs. Hydrobiologia, 363, pp. 13-27.

[59] Dam, H.G., Peterson, W.T. and Bellantoni, D.C. 1994. Seasonal feeding and fecundity of the calanoid copepod Acartia tonsa in Long Island Sound: is omnivory important to egg production? Hydrobiologia, 292/293, pp. 191-199.

[60] Payne, M.F. and Rippingale, R.J. 2001. Intensive cultivation of the calanoid copepod Gladioferens imparipes. Aquaculture, 201, pp. 329-342.

[61] Hernandez, D.E. and Martinez. S.F. 2001. The effect of the culture conditions on the growth and lipid contents of two strains of Nannochloropsis sp. to be used in aquaculture. Hidrobiologia 11(2):163-168.

[62] Sandnes, J.M., Kªllqvist, T., Wenner, D. and Gislerød. H.R. 2005. Combined influence of light and temperature on the growth rates of Nannochloropsis oceanica: linking 
cellular responses to large-scale biomass production. Journal of Applied Phycology 17: 515-52.

[63] Nedbal, L., Tichyacute, V., Xiong, F. and Grobbelaar. J. U. 1996. Microscopic green algae and cyanobacteria in high frequency intermittent light. Journal of Applied Phycology, 8(4/5), 325-333.

[64] Matthijs, H.C.P., Balke, H., van Hes, U.M., Kroon, B.M.A., Mur, L.R. and Binot. R.A. 1996. Application of light emitting diodes in bioreactors: Flashing light effects and energy economy in algal culture (Chlorella pyrenoidosa). Biotechnology and Bioengineering, 50(1), 98-107.

[65] Lim, K.C and Zaleha, K. 2013. Effect of Photoperiod on the Fatty Acid Composition of Three Tropical Species of Marine Microalgae. Malaysian Applied Biology Journal, 42(1): 41-49

[66] Ashraf, M., Javaid, M. Rashid, T., Ayub, M., Zafar, A., Ali, S., Naeem,M. 2011. Replacement of expensive pure nutritive media with low cost commercial fertilizers for mass culture of freshwater algae, Chlorella vulgaris. International Journal of Agriculture and Biology, 13: 484-490

[67] Lee, K.W., Park, H.G., Lee, S.\& Kang, H. 2006. Effects of diets on the growth of the brackish water cyclopoid copepod Paracyclopina nana Smirnov. Aquaculture, 256, 346-353. http://dx.doi.org/10.1016/j.aquaculture.2006.01.015

[68] Phelps, R.P., Sumiarsa, G.S., Lipman, E.E., Lan, H.-P., Moss, K.K., \& Davis, A.D. 2005. Intensive and extensive production techniques to provide copepod nauplii for feeding larval red snapper Lutjanus camperchanus. In: Copepods in Aquaculture (Ed. By C.-S. Lee, P.J. O’Bryen, N.H. Marcus), pp. 151-168. Blackwell Publishing Ltd. Oxford, UK.

[69] Da Grac, M., Melao, A.G., \& Rocha, O. 2004. Life history, biomass and production of two planktonic cyclopoid copepods in a shallow subtropical reservoir. Journal of Plankton Research, 26(8), 909-923.

[70] Milione, M., \& Zeng, C. 2008. The effects of temperature and salinity on population growth and egg hatching success of the tropical calanoid copepod, Acartia sinjiensis. Aquaculture,275,116-123. 
